\title{
XBRL - Revolution in the Digital Financial Reporting of the Romanian Organizations
}

\author{
Mihaela Enachi, „Vasile Alescandri” University of Bacau, Romania
}

\begin{abstract}
The simplification of the transfer of the information from financial statements to the users from different countries, its understanding and correct interpretation before taking decisions require the global unification of the accounting language to optimal fructify the benefits of an efficient and effective communication. Thus, a current concern of the specialists is to develop a universal language for financial reporting, the best achievement to date being represented by the XBRL (eXtensible Business Reporting Language).
\end{abstract}

\section{Keywords}

Financial reporting, information user, XML, XBRL, jurisdiction, specification, taxonomy, XARL.

JEL Code: $M 41$

\section{The coming out and the development of the XBRL language}

XBRL language initiator is Charles Hoffman, who in April 1998, as a member of American Institute of Certified Public Accountants (AICPA) and manager of Knight, Vale \& Gregory in Tacoma, Washington, investigated how the XML (eXtensible Markup Language), a standard used in the exchange of structured documents over the Internet, can be used for electronic reporting of financial information, beginning to develop financial statements prototypes using this standard.

XBRL (eXtensible Business Reporting Language) is a commercial branded language, based on XML, devised with the aim of establishing standardized protocols for the transmission of accounting information through the Internet. [...] XML is a metalanguage; in other words, it represents metadata that are essentially data about other data. These metadata play a fundamental role in facilitating the search for information on the Internet. [...] Accordingly, XBRL as an adaptation of XML to the business world should allow financial information to be managed more effectively and efficiently ${ }^{1}$.

Developed by an international non-profit consortium, XBRL International, consisting of approximately 550 organizations (including here: professional services and consulting companies, financial services and information providers, software and other technology providers, government and non-profit organizations, accounting and trade organizations), XBRL is an open standard, free of license fees, the consortium members inevitably providing a first access to useful information and offering to those interested some advices about the involvement in the implementation of the language.

For the first time, the language was used by AICPA, the American organization of the accounting profession, which is good known, after that being rapidly accepted by many

1 Bonsón, E., Cortijo, V., Escobar, T. (2009), Towards the Global Adoption of XBRL Using International Financial Reporting Standards (IFRS), in the International Journal of Accounting Information Systems, Volume 10, Issue 1, March, Elsevier, Netherlands, pp. 46-47. 
international organizations.

The purpose of XBRL is to facilitate information exchange at global level through the creation of a single vocabulary. So, we can say about XBRL that is a common unified, with specific standards language ${ }^{2}$.

A standardized reporting language helps creating a continuous flux of information between different organizations and enhances the reporting capabilities allowed by technology $y^{3}$.

The main types of activities in the progress of which can be used this language are: the internal and external financial reporting of the organizations; the filing of loan reports; the credit risk assessment; the exchange of information between government departments and between other institutions, as central banks; the exchange of other financial and statistical data.

\section{The introduction of XBRL language in organizations}

To introduce XBRL language within a specific organization you need to contact the local XBRL jurisdiction. On the website of the XBRL International consortium can be found information about the current existing jurisdictions worldwide, their role and organization and steps to go in creating new jurisdictions. These entities mentioned above are countries, regions or international organizations focused on the development of XBRL in their area of action, while seeking to contribute to the international development.

At this moment there are 25 jurisdictional areas (South Africa, Australia, Belgium, Canada, China, Korea, Denmark, Switzerland, France, Germany, International Accounting Standard Board (IASB), GRC-XML, India, Ireland, Italy, Japan, Luxembourg, New Zealand, Poland, Spain, Sweden, United Arab Emirates, United Kingdom, Romania, USA), of which 19 are established and 6 are provisional (China, Switzerland, GRC-XML, India, Poland, Romania). Note that XBRL Romania provisional jurisdiction was approved on 17 November 2009.

The provisional jurisdictions are similar to the start-up organizations with a small working group focused on increasing the interest over the XBRL language in their region and developing an initial taxonomy for local accounting standards. They have two years to become established jurisdictions.

The established or active jurisdictions have a large number of members, several working groups and have significantly progressed in the development and promotion of XBRL taxonomy. They vote for the composition of the International Steering Committee of the XBRL International.

The role of jurisdictions is to promote XBRL language, organize or sponsor the creation of taxonomies, especially for the main accounting standards for business reporting in their area of action. They provide an important education and have a marketing role, explaining the benefits of XBRL to the government, private organizations and supporting the implementation of this language.

\section{Preparing the financial statements in XBRL format}

XBRL creates a common vocabulary for accurate describing financial-accounting information in its all details for its inclusion in a report taking into account the differences of legal regulations and other regulations.

XBRL use does not imply a new standardization of financial reporting, but compliance with

${ }^{2}$ Andone, I. (2004), XBRL - a New Language for Accounting and Finance Professionals, în Revista Informatica Economică, Volum VIII, nr. 2(30), INFOREC Association, București, p. 27.

3 Stoica, M. (2004), E-business Technical Framework, în Revista Informatica Economică, Volumul VIII, nr. 2(30), INFOREC Association, București, pp. 22-23.

${ }^{4}$ Andone, I. (2004), XBRL - a New Language for Accounting and Finance Professionals, în Revista Informatica Economică, Volum VIII, nr. 2(30), INFOREC Association, Bucureşti, p. 26. 
existing standards in the field. It is a flexible language designed to support all current aspects of reporting in different countries and industries and its extensible nature allow it to be adjusted in order to meet particular requirements, even at the organizational level.

For the clarity and transparency of XBRL models the semiotic problems at the users can be prevented. Users know what to expect and what others expect from them ${ }^{5}$.

The idea behind XBRL is a simple one. Instead of treating financial information as a block of text, it provides an identifying tag for each data separately. For example $<$ Assets $>$ is a tag, resulting from the combination of the word "assets" and signs " $<$ " and ">". There are two types of tags, opening tags, such as that in the example above, and ending tags, as this one $</$ Active $>$. Such tags are more than simple identifiers. They describe the structure and meaning of data, providing some information about them, for example if they are monetary ones, percentage or fraction ones. XBRL allows tags to be applied to data, as well as to accounting references and other information, being able to show how the data are correlated one another.

XBRL was designed to allow modular representation of financial information. At the lowest level, financial information is divided into the smallest possible elements, stored in a warehouse. Any XBRL taxonomy can aggregate the elements of information creating in this way financial statements consistent with any global accounting standard ${ }^{6}$.

To support the development process of XBRL taxonomies and the development process of applications which are XBRL compatible, were elaborated specifications, current version being represented by the XBRL Specification 2.1. The specification provides a description of the rules and fundamental principles of the XBRL language.

XBRL taxonomies are dictionaries which the language use, consisting of standard descriptions and uniform classification systems for the content of financial statements and other business reporting documents, referring to schemas and files containing the links between elements.

The role of XBRL schema is to define the elements (concepts used in documents), giving each a name and describing its features. Creating schemas process is realized using $X M L$ Schema technology and their physical form is represented by a file with .xsd extension.

The linkbases between elements, as the second part of the taxonomy, provide information about the relationships between these elements and connects them to specific external resources. There are five different types of such files linkbase: label, reference, presentation, calculation, definition. While the first two files listed are designed to connect elements to external resources, the last three provide a description of relations between elements. These linkbases use two XML technologies, namely, XLink (XML Linking Languages) which allows the creation of hyperlinks in XML documents and XPointer (XML Pointing Languages) which allows the localization of specific parts of XBRL and XML documents.

While the label connects elements to their expressions in a given language and reference connects elements to standards or regulations in the field for a correct interpretation of the meaning of those elements, the other three files provide information on hierarchy of elements using parent-child relationships (presentation), information on the manner a component participate in a total (calculation) and present a series of pre-defined or self-defined links between elements (definition).

As the local jurisdictions have different accounting regulations, each will have its own taxonomy. Moreover, the organizations from the area covered by these can undertake an extension of the existing taxonomy, for example, by adding elements that were not described in the basic taxonomy and which are required, changing relations between elements in terms of orders, but according to some strict rules.

\footnotetext{
${ }^{5}$ Stoica, M. (2004), XBRL Technology in Virtual Organizations, în Revista Informatica Economică, Volumul VIII, nr. 4(32), INFOREC Association, București, p. 34.

${ }^{6}$ Stoica, M. (2004), Business Reports Based on XBRL, în Revista Informatica Economică, Volumul VIII, nr. 3(31), INFOREC Association, Bucureşti, p. 29.
} 
The business report in electronic format created by using XBRL language rules is called XBRL Instance. It is comprised from facts that are defined through the elements of the taxonomy to which it refers, together with their values and an explanation of the context in which they are placed (entity, period, scenario).

The creation and publication of the business reporting documents in XBRL format on Internet allow them to be accessed for any use by investors, creditors, customers, government and its institutions, employees and their representative groups, public.

The basic idea is that through this standard the data collected by the actors of the economic life can be transposed in several formats through automatic processing. One of the objectives of XBRL is the reduction of information asymmetry resulting from incompatible global reporting formats ${ }^{7}$.

While there are many applications that require that business information to be securely transmitted, maintaining the data integrity and confidentiality, where appropriate, XBRL does not provide, deliberately, none of these mechanisms. Its purpose is to allow the transfer of information in an agreed format, being good known the fact that its security can be ensured by a variety of proceedings, such as: signing documents with a private key, encrypting documents etc.

Also, to increase the confidence in modern reporting of financial information it was created a new modern financial audit reporting standard through the Internet.

eXtensible Assurance Reporting Language (XARL), an XML-based extension of XBRL, was designed $[\ldots]$ to enable assurance providers to report on the integrity of XBRL-tagged information distributed over the Internet and help users and companies place warranted reliance on such financial information ${ }^{8}$.

\section{Implementing XBRL language in Romania}

It is known the fact that in Romania the electronic communication of financial-accounting information in a pre-defined form is partly allowed (only for some components of the financial statements), and it goes in this form to the local financial administrations or general directorates of public finances. Therefore, other users interested in the business of the organization need often to transcribe this information before interpret it, and even the government does not have a sufficient easy to work with source of information.

XBRL language isn't required in Romania as a reporting standard yet, but there are efforts in this regard, a first step being represented by the creation of a provisional jurisdiction, which now prepares to launch its website (currently with a content under construction) and for the campaign on getting members, for the beginning in the idea of creating a corporate governance structure within the association.

The elaboration of a taxonomy by Romania, in compliance with national regulations and in accordance with International Accounting/ Financial Reporting Standards (IAS/IFRS) allows formalizing the financial statements components and thus their speedy transposition, as we previously mentioned, from the format specific to a country to the format specific to another country, reducing in this way the costs of exchange, conversion, interpretation of information by different users.

Thus, the introduction of the characteristics of XBRL language automatically generates the processing of the information in accounting, eliminating in this way, through remaking, the

\footnotetext{
${ }^{7}$ Premuroso, R.F., Bhattacharya, S. (2008), Do Early and Voluntary Filers of Financial Information in XBRL Format Signal Superior Corporate Governance and Operating Performance?, in the International Journal of Accounting Information Systems, Volume 9, Issue 1, March, Elsevier, Netherlands, p. 5.

${ }^{8}$ Efrim Boritz, J., No, W.G. (2005), Security in XML-Based Financial Reporting Services on the Internet, in the Journal of Accounting and Public Policy, Volume 24, Issue 1, January-February, Elsevier, Netherlands, p. 14.
} 
costs and elaborate work that the calculation imposes, the data analysis and comparison. We owe this fact to computers which, once they are equipped with this program, they treat data in an intelligent manner: they acknowledge the information that is contained within a XBRL document, selects it, analyzes it, deposits it and provides the interested users with it.

It is desirable that the implementation of XBRL language in the Romania organizations occur involving the government which to provide adequate resources, professional organizations (The Body of Expert and Licensed Accountants of Romania (CECCAR), The Chamber of Financial Auditors of Romania (CAFR), The General Association of Economists of Romania (AGER), The Romanian Chamber of Fiscal Consultants (CCF) etc.) and universities which to provide professional support for instruction in the implementation and use of XBRL at the highest levels.

\section{The advantages of using XBRL}

Those who can benefit from the use of XBRL format in the financial reporting are those who collect financial information (investors, creditors, stock exchanges, financial information company, statistical institutes, governments etc.) and those who produce this information for internal and external use.

Like benefits of using this language note: reducing costs and increasing the speed of the processes of collecting, processing and reporting financial information; faster and easier access to information in real time updated, implicitly faster and better taking decisions; process automation, which is leading to simplifying and automating tasks and reducing the possibility for errors to occur; increasing the quality of information and confidence in it for all those involved in its supply or use; improving the relations with users by providing more transparent and friendly to use information; the intelligently treatment of information, being possible its recognition in a XBRL document, selection, analyzing, storing, exchanging with other computers and automated presentation in a variety of forms for users; easy operating with information, even if it is in different languages and performed in accordance with different standards, taking into account the fact that the XBRL language can be very easily adapted.

Among the main beneficiaries of XBRL adoption by organizations, in Romania would be: The Government, The Finance Ministry, The Body of Expert and Licensed Accountants of Romania, The Chamber of Financial Auditors of Romania, the local financial administrations, the General Directorate of Public Finances, the financial-banking system, the interim agencies and bodies of European funds administration, national investors, various economic agents.

XBRL has revolutionized business reporting around the world, mainly through its essential advantage consisting in the unification of financial-accounting language, which facilitates the directly and without conversion exchange of information between the actors of the economic life.

\section{References}

1. Andone, I. (2004), XBRL - a New Language for Accounting and Finance Professionals, în Revista Informatica Economică, Volum VIII, nr. 2(30), pp. 26-29, INFOREC Association, Bucureşti

2. Bonsón, E., Cortijo, V., Escobar, T. (2009), Towards the Global Adoption of XBRL Using International Financial Reporting Standards (IFRS), in the International Journal of Accounting Information Systems, Volume 10, Issue 1, March, pp. 46-60, Elsevier, Netherlands

\footnotetext{
${ }^{9}$ Munteanu, V. (2006), Present-Day Financial Statement and the Foundation of Economic Decisions, in Romanian Economic Business Review, Volume 1, Issue 2, Romanian-American University, Bucureşti, p. 11.
} 
3. Efrim Boritz, J., No, W.G. (2005), Security in XML-Based Financial Reporting Services on the Internet, in the Journal of Accounting and Public Policy, Volume 24, Issue 1, January-February, pp. 1135, Elsevier, Netherlands

4. Munteanu, V. (2006), Present-Day Financial Statement and the Foundation of Economic Decisions, in Romanian Economic Business Review, Volume 1, Issue 2, pp. 7-13, Romanian-American University, Bucureşti

5. Năstase, F. (2000), Standarde deschise pentru comertul electronic, în Revista Informatica

Economică, Volumul IV, nr. 4(16), pp. 31-41, INFOREC Association, Bucureşti

6. Premuroso, R.F., Bhattacharya, S. (2008), Do Early and Voluntary Filers of Financial Information in XBRL Format Signal Superior Corporate Governance and Operating Performance?, in the International Journal of Accounting Information Systems, Volume 9, Issue 1, March, pp. 1-20, Elsevier, Netherlands

7. Stoica, M. (2004), Business Reports Based on XBRL, în Revista Informatica Economică, Volumul VIII, nr. 3(31), pp. 27-30, INFOREC Association, Bucureşti

8. Stoica, M. (2004), E-business Technical Framework, în Revista Informatica Economică, Volumul VIII, nr. 2(30), pp. 22-25, INFOREC Association, Bucureşti

9. Stoica, M. (2004), XBRL Technology in Virtual Organizations, în Revista Informatica Economică, Volumul VIII, nr. 4(32), pp. 33-36, INFOREC Association, Bucureşti

10. http://www.iasb.org/XBRL/

11. http://www.tryxbrl.com/

12. http://xbrl.org/

13. http://xbrl.squarespace.com/

14. http://xbrlblog.com/ 